\title{
INDUSTRIALISATION AND URBAN GROWTH IN NORTH-EAST ENGLAND*
}

The twin processes of industrialisation and urbanisation lie at the heart of the evolution of modern British society, in North-East England as in other areas of large scale industrial development. ${ }^{1}$ Despite the cardinal importance of the interaction between these two processes the relationship is only very imperfectly understood; this weakness is in part due to the limited amount of investigation which has taken place, in part to serious deficiencies in the surviving evidence, and in part to the inherent complexity of the subject. As yet, for example, we have no adequate studies of the major industries of the region, including coal-mining and shipbuilding, while our knowledge of the development of urban communities is very far from complete. In addition much of the archaeological evidence for the older parts of the industrial communities has disappeared, or is disappearing, often without adequate study or record. In these circumstances an essay on the relationship between industrialisation and urbanisation in North-East England must be tentative and limited, and should be seen as an attempt to bring together some of the available material rather than one which offers an explanatory model.

* I should like to express my gratitude to the Institute of Social and Economic Research, University of York, for providing me with facilities as a Visiting Scholar for the academic year 1974-75. My share of this article was written there and the typescript of the final version undertaken with its secretarial facilities. D.J.R.

1 The question of the definition of an urban area is one in which a variety of criteria could be employed. Population in itself is not always a satisfactory guide, for a Census figure may relate to a group of scattered communities within a limited area rather than to one coherent town, while a place of only moderate size might perform commercial, administrative or social functions which appear characteristically urban. An extended discussion of this problem of terminology would be out of place here. There will always be communities whose urban nature is debatable, but in this paper we have tried to concentrate our discussion on communities which can be considered towns by most criteria, including size and function. 
The slightest examination of the evidence suggests the existence of a link between the two major developments. The decline in the proportion of the occupied population employed in agriculture and the concomitant rise of the proportion employed in extractive and secondary industry was accompanied by a major and rapid increase in total population and in the proportion living in large communities. Between 1821 and 1911 the proportion of the population of North-East England living in communities of less than 2,000 fell from more than $60 \%$ to $25 \%$, while the proportion living in towns of more than 50,000 rose from nothing to more than $40 \%{ }^{1}$ Towards the end of the nineteenth century the rate of population growth declined, and this trend was accompanied by a stabilisation in the proportion employed in extractive and secondary industry and an increase, still continuing, in the proportion employed in tertiary occupations. Throughout this later stage, urbanisation has gone on apace, encouraged by improvements in communications and the general acceptance of new standards of social amenities.

Any serious study of these developments at once reveals that the relationship between industrialisation and urbanisation has been neither simple nor uniform, but one which varied from place to place, from industry to industry and from time to time. Among the major factors, which will recur throughout this paper, mineral resources, geographical situation, transport facilities and the actions of individual entrepreneurs were significant causes of industrial growth and the siting of urban communities. The mining of coal, for instance, led to the development of urban areas which may not have occurred but for the existence of that resource, and this was also true of the mining and manufacture of iron. The siting and development of these industries had further effects in the creation of urban communities at convenient points on coast and rivers for shipping their output. In these examples of the creation of new communities industry had an impact which was very different from the impact of the gradual accretion of new industries by existing communities. The rise of new communities was not, however, solely directed by natural resources. The railway facilitated development in areas which were previously inaccessible to largescale industrial growth, while the development of some communities was heavily dependent on the initiative and, at least initially, on the financial activities of one or more individuals.

1 J. W. House, North-Eastern England: Population Movements and the landscape since the early 19th century [University of Durham, King's College, Dept of Geography, Research Series, No 1] (Newcastle upon Tyne, 1954), p. 56, Table 2. 
Neither industries nor towns were new developments of the nineteenth century. There had been towns of moderate size before, especially Newcastle upon Tyne, and also industries of importance, notably coalmining. Indeed the eighteenth century had already shown a remarkable expansion of industry in comparison with any earlier period. In glass and textiles, for example, as well as coal, there had already been growth, accompanied by a beginning of the urbanisation which was to become so much more obvious in the nineteenth century. Moreover, it was already clear that early industrial development did not always lead to the development of established urban communities. Belford, in North Northumberland, provides a good example here. When Arthur Young visited the area in 1770 he described how Abraham Dickson, who owned most of Belford, had established a woollen mill, a tannery, collieries and lime kilns; "thirteen years ago it did not contain above 100 souls [...] they now amount to above six times that number". 1 Even the enterprise of an alert landowner could not, however, overcome the inherent disadvantages of Belford's limited natural resources and transport facilities, and its emergence from a predominantly rural existence was to be brief. A survey of local directories for the late eighteenth and early nineteenth centuries discloses many other instances of small-scale initiative in industrialisation which never blossomed into the creation of new urban areas.

In the early industrial development in the region coal-mining was of greatest importance, but the impact of its expansion on urbanisation was also neither simple nor uniform. The consequent growth of population was often on a limited scale, and the sinking of a new pit in the early nineteenth century might lead to the creation of a separate colliery village of 2,000 inhabitants or even much less. In a variety of ways, however, the growth of coal-mining had both direct and indirect effects on the development of the urban communities of the region.

Although the mining of coal is not normally considered a specifically urban phenomenon and there are now relatively few collieries in major urban settings within the region, it was certainly true that coal-mining was the most important single factor in the early concentration of population in urban areas. In Newcastle, Gateshead, North and South Shields, Wallsend, Jarrow and Sunderland, the establishment of coal mines in the immediate area played an important direct role in the growth of population. This development often began as the creation of a separate mining nucleus, some little distance away from the existing town, only to become absorbed as the communities concerned ex-

1 A. Young, A Six Months Tour Through the North of England, III (1770), pp. 50-58. 
panded. At Gateshead, for instance, where the early growth of the town had already owed much to the exploitation from Elizabethan times of the coal mines under the Grand Lease of the Manors of Gateshead and Whickham, Redheugh Colliery, within the town's built-up area, was worked until 1927. At North Shields, part of the town's growth in the nineteenth century involved the effective absorption of Percy Main and Preston, outlying areas which had already seen separate growth as mining communities. At Newcastle, the winning of the Spital Tongues colliery on the outskirts of the town in the early 1840's brought about the creation of a mining community there, which by 1870 had clearly become absorbed within the growing regional metropolis. In this way the major urban areas were extended more rapidly than would have been the case if there were no such established communities to absorb.

Between 1822 and 1854 the total number of sea-sale collieries in the region grew from 62 to 184 , and the productive capacity of the coalfield approximately doubled from circa 5.4 million tons to circa 10.3 million tons. Much of this growth came as a result of the opening-up of new areas of the coalfield, and there was a consequent creation of new communities. The rapid expansion of mining in East Durham drew this comment from a Sub-Commissioner to the Royal Commission on the Employment of Children in 1841:

"Within the last ten or twelve years an entirely new population has been produced. Where formerly was not a single hut of a shepherd, the lofty steam-engine chimneys of a colliery now send their volumes of smoke into the sky, and in the vicinity is a town called, as if by enchantment, into immediate existence."1

Not all of the East Durham mining communities could fairly be considered as towns, but the expansion of coal-mining in that area was to produce local centres. It sometimes happened that the expansion of mining produced not the creation of something entirely new, but the transformation of the character of an older community. Hetton-leHole, described as "a hamlet" in a directory of $1808,{ }^{2}$ saw its population expanded by coal-mining from 264 in 1811 to 5,900 in 1831, and what had been merely "a hamlet in the parish of Houghton-le-Spring" was already emerging as something of a local centre serving the needs of smaller mining communities in the immediate vicinity. Similarly in South-West Durham the sinking of Woodhouse Close Colliery in 1837, followed in the next year by West Auckland Colliery, hastened the transformation of the old market town of Bishop Auckland, with its

1 Royal Commission on the Employment of Children [1842], Appendix to First Report of Commissioners, Mines, Pt I, p. 143.

B. P. Capper, A Topographical Dictionary of the United Kingdom (1808). 
episcopal palace, into what was predominantly a mining town.

Indirectly, too, the expansion of coal-mining affected the growth of towns in a variety of ways. These developments came mainly along the rivers and coasts because of the growing need to improve the transport facilities for coal. They included the extension of shipbuilding and shipowning, the creation of improved facilities for loading coal into ships and the complex commercial facilities for shipping and marketing coal. As with the direct influence of coal, this could involve either the creation of completely new urban communities or the substantial alteration of older settlements. The growth of coal-mining was one important factor, for example, in the extension of employment and population in Newcastle, which was the chief centre of the commercial facilities for the coal trade. On both banks of the Tyne, the provision of new docks, largely connected with the coal trade, had important effects on those communities which were based on the older port facilities. On the North bank the building of the Northumberland Dock (1857) and the Albert Edward Dock (1884) accelerated the creation of a kind of ribbon development, which produced a virtually continuous stretch of housing and industry (some of it now destroyed), linking together the expanding towns of North Shields and Wallsend. At South Shields the creation of the Tyne Dock (1859) produced a similar result. There the expansion in trade was even more spectacular than on the opposite bank. While in 1800 only some 1.6 million tons of coal were shipped from the Tyne, in 189412.2 million tons were shipped, and 5.6 million tons of this passed through Tyne Dock, a figure unsurpassed anywhere in the world. This extension of the facilities at the old ports was inappropriate as an outlet for the production of the newly opened areas of the coalfield. But the railways, whose development had caused the expansion, provided the opportunity to develop new shipping areas. The Tees was opened up as the shipping outlet for coal from the South-West Durham field, and important new harbours were established on the Durham coast.

In the early nineteenth century transport facilities were such that a ton of coal which fetched four shillings at a colliery near Bishop Auckland cost eight shillings at Darlington and twelve at Stockton. When Joseph Pease was calculating the probable impact of the Stockton and Darlington Railway in 1825, he estimated a reduction of nearly onehalf in the price of coal at Darlington and more than one-half at Stockton. ${ }^{1}$ It was not, however, merely the impact on local price levels which was important, although that would certainly increase demand and encourage the development of coal-using industry; much more im-

1 N. Sunderland, A History of Darlington (Darlington, 1968), pp. 61, 67. 
portant was the opportunity for competitive entry into the lucrative sea-sale trade. Around 1800 it had cost less to send a ton of coal from Newcastle to London by sea than to move it ten miles overland from the Auckland coalfield. A reduction from the wagon cost of 4-5d per ton/mile to the average cost on Durham coal railways by 1840 of about $1 / 3 \mathrm{~d}$ per ton/mile meant a significant improvement in the competitive position of the collieries of South-West Durham. Although the opening of the Stockton and Darlington Railway brought the beginning of this development, it was not until the railway was extended from Stockton to a deeper water site in 1830 that the real break-through occurred, and the town of Middlesbrough appeared on the scene. In 1828-29 the railway carried 46,216 tons of coal, in 1830-31 152,262 tons, and in 1832-33 336,000 tons. The effect of this industrial change on urbanisation was rapid and striking. Middlesbrough's population had crept up from 25 in 1801 to 150 in 1831 , but the Census of 1841 showed a population of $5,463 .{ }^{1}$

Middlesbrough was not the only town to develop as a result of the expansion of coal-mining and railways. With the development of the East Durham coalfield it became clear that coal might be shipped more expeditiously and cheaply from coastal sites than from the river ports. In 1832 the Hartlepool Dock and Railway Company was authorised to build a railway into the East Durham coalfield, with branches to various collieries, and also to rebuild and extend the harbour of the ancient borough of Hartlepool. By 1841 this railway was carrying more coal than any other line in the North of England; $27 \%$ of the coal shipped from North-East ports passed along its tracks. ${ }^{2}$ The population of the old town of Hartlepool jumped, as a consequence, from 1,330 in 1831 to 5,256 in 1841, and the dependence of this growth on coal may be seen from the fact that in 1839 the railway derived only $6 \%$ of total revenue from passenger traffic and only $4 \%$ from the carriage of goods other than coal. The building of the Stockton and Hartlepool Railway soon provided a link which diverted to the new and convenient coastal shipping facilities at Hartlepool much of the coal which had earlier been loaded at Middlesbrough, avoiding the more difficult passage along the River Tees to the sea. The Hartlepool Dock and Railway Company did not welcome the appearance of this formidable competition from collieries which their lines did not serve, and provided poor shipping facilities for the new company.

This attitude provoked a powerful response from the champions of

1 Sir G. Head, A Home Tour Through the Manufacturing Districts of England in the Summer of 1835 (1836), pp. 298-306, described some of these developments. 2 R. Wood, West Hartlepool (West Hartlepool, 1967), p. 13. 
the Stockton and Hartlepool line and their associates. Under the driving leadership of Ralph Ward Jackson they set about providing their own alternative facilities for shipment. In 1844 an Act was obtained for the building of a new harbour near the village of Stranton, just to the south of Hartlepool. The first coal-shipping dock, at what was then known as Hartlepool West Harbour, was opened in 1847, and within the next decade a completely new town, West Hartlepool, was created and soon outstripped the older borough to the north, as the new harbour expanded to become for a while the fourth port in the United Kingdom in terms of tonnage handled. A second dock was added in 1852 and a third in 1856 . The port built up such complementary trades as a large-scale import of timber to meet the needs of the collieries for pit-props and other wooden products. The basic dependence on coal, however, was clear. It can be seen in the vigour with which Ralph Ward Jackson and his successors as local leaders steadily expanded the port's coal-shipping facilities, expanded the railway connections to new collieries, and encouraged the settlement of coal-using industry. Shipbuilding and engineering in consequence strengthened the town's economy, as did the establishment nearby of Bell Brothers' important iron works.

Although the general picture is one of spectacular growth, West Hartlepool, like other towns, experienced occasional setbacks. One report to the Home Office commented:

"West Hartlepool [...] has gone through more than one commercial panic, the last and most noticeable being that of 1866. It is, in consequence, a half-finished place, with gaps and unoccupied building sites left in some of the principal streets, and here and there a piece of waste ground, wide enough for a street, with hardly a house erected on either line of frontage."

The collapse of the important shipbuilding firm of Pile, Spence and Co. in 1866 had caused severe depression, but these works with their associated rolling mills re-opened in 1869 under a new company, Denton, Gray, which was to become one of the largest shipbuilding yards in the country. In the same year a local newspaper could comment that "Other firms have enlarged their premises, new firms have sprung into existence; the shipping trade has improved, and the consequence is that during the past year the population is supposed to have increased by not less than 5,000. With this influx of artisans large numbers of new streets have been built and wooden dwelling houses have become familiar objects."' West Hartlepool's population grew from 4,008 in 1 Quoted in Wood, op. cit., pp. 116, 115. In six years between 1878 and 1900 Grays had the largest output of any British shipbuilding yard. The construction 
1851 to 13,601 in 1861 and 60,561 in 1901 , by which time it was more than four times as large as the old town of Hartlepool.

Further north along the coast a similar story had begun at an appreciably earlier date, at Seaham. Plans for a harbour there had been in the air for some time before the estate came into Lord Londonderry's hands, but they were of limited prospects until the cost-reducing effect of the railways on the carriage of coal was made explicit. Londonderry owned a number of important collieries in the Penshaw area, and foresaw considerable advantage from a co-ordinated system of collieries, railways and port under a single control, not least the chance of escaping from dues charged for coal shipment; he wrote:

"there is a fair prospect hereafter of making a better harbour of our own than Sunderland for a large export of our coals, bringing them by railway of four miles from our freehold collieries to the port, and supplying all this coast free of port duty of Sunderland with our own coals, giving us thus an increased channel for our supply without the tax of six shillings a chaldron, which we pay now at Sunderland for port duties."1

Between 1828 and 1831 an entirely new harbour was constructed at a total cost of some $£ 300,000$, and this provided the basis for what Lord Londonderry regarded, not without reason, as "my town of Seaham Harbour". Here, however, urban growth was to prove distinctly more limited than at West Hartlepool. The original harbour was too small to cope with the growing output of the Londonderry collieries, and in 1854 the Londonderry Railway was extended to the Hendon Dock at Sunderland, though at Seaham there were some important later developments, notably a considerable re-building and extension of the harbour in the early twentieth century. The population grew from 35 in 1821 to 6,000 by 1861 and to over 10,000 by 1901 .

The effects of mining expansion on urbanisation were already obvious by mid-century, but continued apace in the later nineteenth century, both in the extension of existing communities and the creation of new ones as new areas of the coalfield were opened up. Many of the later collieries were on a much larger scale than earlier enterprises, and demanded a work force capable in itself of forming an urban settlement. On the East Durham coalfield Ryhope grew from a population

of wooden houses, which also occurred in a number of colliery villages, always appears to have been a reaction to a very rapid increase in population, which had outrun the usual resources of the building industry.

1 Quoted in D. Spring, "English Landowners and Nineteenth-Century Industrialism", in: Land and Industry, ed. by J. T. Ward and R. G. Wilson (1971), pp. $48-49$. 
of 475 in 1851 to 9,592 by 1901, while Wingate, by the extension of the local pits, rose from 4,463 in 1891 to 8,005 in 1901. In North-West Durham, for example, Chopwell increased in population from 788 in 1871 to 4,183 in 1901 as mining expanded. Similar examples of rapid growth took place with the opening-out of the Northern part of the South-East Northumberland coalfield. Until the railway development of the 1840's this area had been largely neglected and its steam coal in limited demand. But industrial and technical development in the second half of the century brought such an expansion of demand that Ashington's population grew from 345 in 1851 to 13,956 in 1901, ${ }^{1}$ and Bedlington's from 5,101 to 18,766 .

As well as being important mining centres themselves, these towns and similar ones in Durham, such as Houghton-le-Spring, also came to provide a variety of services, such as shopping facilities and entertainment, for a group of smaller mining communities in the neighbourhood. In a period in which travel was restricted it is not surprising that such centres developed as the "market towns" for the growing populations of the mining regions. Again this growth of coal-mining in the second half of the nineteenth century produced corresponding growth in dependent sectors. In the 1880 's, for instance, the navigation of the River Blyth was improved and new staithes constructed to handle much of the coal from the Bedlington-Ashington area. Coal shipments from Blyth rose from 235,000 tons in 1880 to 1.8 million in 1890 and to over four million by 1914. The town's population more than doubled between 1871 and 1901.

While coal-mining stands out as the major growth point in the region's early economic expansion, it was certainly not the only one. Towns such as Newcastle, Gateshead and Sunderland had a wide variety of industry as early as 1800 , and there were a number of early examples of inter-locking enterprises, with the same men controlling connected processes or a combination of raw materials and manufacture. For example, Isaac Cookson, who came to Newcastle from Cumberland about 1720 , built up a complex pattern of economic interests based on membership of a number of different partnerships, apart from his role as Newcastle's leading gold and silver smith. He had colliery interests and in 1745 erected the first coke-fired blast furnace in the region near Chester-le-Street. On Tyneside he had several foundries; one was in

1 The Censuses record a growth for Ashington itself from 345 to 6,284 . But the rapid growth of mining in the 1890's saw the extension of the urban area into the parish of Hirst, what was to be known in Ashington as living at "the Hirst end". Here population rose from 57 in 1891 to 7,672 in 1901 . 
The Close, Newcastle, another, in partnership with Joseph Button, in Gateshead, while his steel interests included sites at Derwentcote and Blackhall Mill on the River Derwent. During the French Revolutionary War Cooksons, together with Hawks of Gateshead, were among the largest contractors for government armaments orders. Nor did this exhaust the list of the varied interests of the Cookson family, which also included glass works at the Ouseburn and at South Shields, as well as at Newcastle, and an establishment for refining antinomy. The activities of this one family in the late eighteenth and early nineteenth centuries thus played a part in providing employment and increasing population in the towns of Newcastle, Gateshead and South Shields, and also in much smaller communities. It is not surprising to find Cooksons in leading positions in the civic life of the regional centre, Newcastle, for year after year.

In these relatively unsophisticated times, many lesser men also figured in a wide variety of enterprises. There were many men in the 1820's like George Ramsay of Winlaton, who manufactured fire-bricks, sal ammoniac, flint and colours for painters, and was also a merchant of bone ash and manure, pantiles and bricks, and a maltster. Ramsay's various enterprises inter-locked with each other to a great extent, and also helped to fit in with the overall needs of the district's economy; they combined to provide employment and resources, which in turn stimulated demand and further growth in such enterprises.

The story of the textile industry in the North-East during the earlier nineteenth century provides an illuminating contrast to the expansion of coal-mining, for here the extent of successful development was markedly more patchy. When the century began, Darlington was already a noted textile centre and Barnard Castle was also regarded as a manufacturing town of some importance in that field, but a glance at early directories shows a very much wider distribution. Textile manufacture was also carried on at Alnwick, Mitford, Berwick, Corbridge, Haltwhistle, Hexham and Morpeth - none of them places which would nowadays spring to mind as notable manufacturing centres. Some of this scattered industry contrived to enjoy a lengthy existence. At Acklington Park in Northumberland an earlier ironworks was converted into a blanket mill in 1791, and the factory continued at work until 1930 . The Otterburn tweed mill, founded in 1821, is still at work today. Much of this scattered small scale activity was, however, short-lived, and never provided a focus for urban growth. South-East Durham provides a good example. A directory of 1793 recorded the erection of a large cotton mill on the outskirts of Castle Eden, but a directory of 1828 tells a different story about this site: "Factory, a hamlet half a mile south of Castle Eden where there was formerly an extensive cotton manu- 
factory, but it has long since gone to decay, though the cottages built for the workmen are still remaining." 1

Darlington provided for many years a notable exception and, while in the early nineteenth century it possessed a variety of other industrial enterprises, such as the production of optical glass, it was predominantly a textile town. By the late 1820's there were nine linen and seven woollen and worsted factories in the town. The water power of the River Skerne attracted spinners, while the demand for weavers stimulated growth in a number of satellite communities; a hundred linen weavers, for instance, lived in 1820 at Great Aycliffe, a village five miles north of Darlington. ${ }^{2}$ The significance of the textile industry may be seen from the fact that in 1831 it employed $25 \%$ of Darlington's adult males, in addition to a significant number of women. However, even this larger-scale textile manufacture failed to provide a secure base for the economic life of a growing town, and Darlington's growth in the later nineteenth century was to rest on railways and iron and steel, not on linen, woollens and worsted. ${ }^{3}$ We know little in detail of the reasons for the decline in importance of the region's textile enterprises, but there is no reason to doubt that they were basically similar to the disadvantages which crippled such areas as the West Country and East Anglia, including poorer organisation, slower adoption of new technology and less opportunity for the scale economies which were enjoyed by the booming centres of Lancashire and the West Riding.

At the other end of our region, another town presents a very different example of the varied ways in which industrial development could stimulate a town's growth. Berwick was an old established town and a seaport, and by the 1820's possessed a wide range of small scale industry, including textiles, rope-making and iron-working. These were not, however, the core of the town's economy. Early-nineteenth-century Berwick depended much more on its role as part of the machinery which provided food to the growing non-agricultural population elsewhere, especially in London, the country's greatest industrial centre as well as the centre of administration. Berwick expanded as a centre of fishing and as the entrepôt for the rich agricultural hinterland, including the Tweed valley. In 1816, for example, Berwick sent nearly five thousand chests of eggs to London, of a total value of some $£ 30,000$.

1 W. Parson and W. White, History, Directory and Gazetteer of the Counties of Durham and Northumberland, etc., II (1828), p. 265.

2 Ibid., p. 213.

3 B. Barber, "The Concept of the Railway Town and the Growth of Darlington 1801-1911: A Note", in: Transport History, III (1970), pp. 283-92; K. Warren, The Geography of British Heavy Industry since 1800 (1976), pp. 45-46. 
The fleet of sailing smacks which carried fish from Berwick down the East coast to London gradually gathered to itself much of the coastal trade. Berwick was not, however, to maintain these sources of growth. French competition gradually eliminated Berwick's position as supplier of eggs to London, while an injudicious piece of imperialism lost to Berwick much of its lucrative East-coast trade; an attempt to extend Berwick's hegemony in coastal shipping to the Forth produced a spirited response from the Leith merchants, who built bigger and better ships than the Berwick smacks, and not only beat off the challenge but went on to take over much of Berwick's previous trading empire down the East coast of England. ${ }^{1}$

Some industries which prospered in the nineteenth century saw considerable local vicissitudes within an overall pattern of expansion. If iron and steel played a major part in the later development of the Southern part of our region, there was an earlier chapter of less distinction. From 1799 onwards a number of blast furnaces were established in Northumberland and Durham to take advantage of local deposits of siderite (clay-band ironstone) together with locally available coal. ${ }^{2}$ Among these were Lemington-on-Tyne (1799), Wylam (1836), Redesdale (1836) and Hareshaw near Bellingham (1838). These enterprises brought significant increases in local populations, with the need for furnace workers, miners of iron and coal, and quarrymen for limestone, but although some of them continued a precarious existence into the second half of the century, none of them achieved sufficient success to create stable urban communities. It was only where blast-furnace plant could be carried on in conjunction with iron-using industries that iron manufacture in the Northern part of the region could meet the challenge from Teesside in the second half of the century. The isolated ironmanufacturing communities, especially in rural Northumberland, could not compete with the better access to superior raw materials, transport facilities and the significant economies of scale possible on Teesside. Even on Tyneside the iron works, which were either part of or close to the shipbuilding and engineering complexes, were largely closed down by the end of the century. Nevertheless in these places the closure of iron manufacturing plant had little effect on the long-run existence of the urban communities. As at Tow Law, in Durham, where the iron

1 Parson and White, op. cit., pp. 374-75.

2 See I. L. Bell, "On the Manufacture of Iron in connection with the Northumberland and Durham Coal-field", in: British Association for the Advancement of Science, Report of 23rd Meeting held at Newcastle upon Tyne, 1863 (1864), pp. 730-64; T. M. Hoskison, "Northumberland blast furnace plants in the nineteenth century", in: Transactions of the Newcomen Society, XXV (1945-47); and R. F. Tylecote, "Recent Research on Nineteenth Century Northumbrian Blast Furnace Sites", in: Industrial Archaeology, VIII (1971). 
works, which had initiated urban growth, closed in the 1880's, there were enough other industrial enterprises in the district to sustain the urban community.

With some failures and some set-backs, however, it remains true that even in the first half of the nineteenth century the twin forces of industrialisation and urbanisation were proceeding at a rate which was remarkable by the standards of any previous period, though as yet less impressive than the rate of growth in the industrial districts of Lancashire and Yorkshire.

At Newcastle, the region's principal town, population rose from 28,294 in 1801 to 87,784 in 1851 after the Municipal Reform Act of 1835 had extended the legal limits of the borough to include the outlying districts of Elswick and Westgate to the west, Jesmond to the north, and Heaton and Byker to the east. 1 The distinctively urban area did not, however, match the growth in population. In part this was due to such practical considerations as the need for workers to live within walking distance of their employment and the rent they could afford for accommodation. In part also other considerations cramped the town's physical expansion. Newcastle was an old walled town and, although substantial stretches of the medieval wall were demolished during the period 1795-1815, extension beyond this enclosing perimeter was relatively slight in the first half of the nineteenth century. The pattern of land tenure also imposed limitations; Anderson Place, a substantial house with extensive grounds, blocked one area of potential expansion to the north of the old town until the later 1830 's, while at some little distance further out extensive tracts of inalienable common land - the Town Moor, Nuns Moor and the Leazes - inhibited development away from the riverside. The swollen population was, therefore, largely concentrated within the old town or in a limited belt of expansion to east and west along the river frontage. The siting of some of the town's early industrial enterprises facilitated this. The lower part of the valley of the Ouse Burn, which entered the Tyne to the east of Newcastle, became an early industrial suburb, and from there to the west of the town the river frontage was the centre of industry. In 1817, for instance, Robert Hawthorn, son of Walbottle colliery's engine man, set up a small engine shop at Forth Banks, above the river, in Newcastle itself. In 1820, when the original work force of four had grown to 34 , his brother William joined him as partner; by mid-century this

1 On the basis of constant 1801 boundaries the population of the town rose from 28,294 in 1801 to 42,760 in $1831,49,860$ in 1841 , and 57,763 in 1851 . For the same dates the figures for the post 1835 boundaries were 32,$976 ; 53,613 ; 70,337$; and 87,784 . 
firm alone was employing not far short of a thousand men in central Newcastle. ${ }^{1}$ With a great deal of industrial development concentrated either in or very near the old riverside town it is not surprising that at mid-century a Newcastle guide book could describe Barras Bridge and Brandling Park - little more than a mile north of the quayside - as "the pleasure abodes of the affluent".

At South Shields, too, the pattern of land ownership played a significant part in influencing both industrialisation and urban expansion. A great deal of the land in that area was owned by the Dean and Chapter of Durham, and 21-year leases were the maximum lettings allowed. In the early nineteenth century this restriction had only limited effects in discouraging enterprise, for the Dean and Chapter regularly adopted a liberal policy in the renewal of leases. Two developments of the 1830's brought contrasting effects. On the one hand the negotiations surrounding the creation of Durham University brought legislation which allowed the Dean and Chapter to sell a limited amount ofl and at South Shields, while on the other hand the advent of the Ecclesiastical Commission as landlord for the remainder imperilled security of tenure by a threatened termination of the custom of automatic renewal of leases. During the 1840's and 1850's the threat of precarious tenure or heavy fines on renewals of leases brought considerable uncertainty to aspiring entrepreneurs and it was not until well into the second half of the century that this situation was remedied and long term security of holdings made possible. ${ }^{2}$

Gateshead, too, illustrates some of the varied ways in which land tenure could restrict urban growth. Until the 1850's and again in the period 1875-85 there was a shortage of building land, since the town was encircled by the river and the Park, Shipcote, Saltwellside and Redheugh estates. As a result,

"In 1831, the bulk of Gateshead's 15,177 inhabitants lived in and around the riverside nucleus of the town, in seriously overcrowded conditions. Little house-building had been done since 1801 when the population had been just over half that total [...]. As growing industries attracted greater numbers of people into the town, the existing stock of housing became increasingly inadequate to cope. The census of 1831 revealed that 3,429 families were living in 2,197 houses and only 43 houses were in the course of erection." 3

It would be wrong, however, to exaggerate the degree to which 1 Historical Sketch of the Forth Banks Engine Works (Newcastle, 1887) gives in Appendix I (p. 14) a table of the growth of the work force from 1817 to 1874.

2 G. B. Hodgson, The Borough of South Shields (Newcastle, 1907), pp. 157-59.

${ }^{3}$ F. W. D. Manders, A History of Gateshead (Gateshead, 1973), pp. 162-63. 
shortage of available building land was responsible for bad housing conditions. It seems probable that there was some land available for building purposes in all the region's towns and yet, restricted or not, all of them showed about 1850 the same pattern of grossly over-crowded and unhealthy centres, as all the contemporary public health reports suggested. This seems most explicable in terms of rents rising more rapidly than earnings. It is worth remembering, though, that these conditions were not the prerogative of distinctively industrial towns or indeed of towns at all. In the country town of Alnwick in 1850 Teasdale's Yard and the White Hart Inn yard presented black spots very similar to those in Tyneside towns, while mid-century sanitary reports had some unpleasant things to say about sanitary and housing conditions in a rural village like Embleton or a fishing hamlet like Boulmer. ${ }^{1}$ Nevertheless the sheer size of the concentration of population in the developing industrial towns produced the more serious effects, and the basic cause was often a simple matter of economics - the cost of housebuilding related to the capacity of the poorer sections of society to pay rent.

In Gateshead, from about the 1820's, those who could afford to do so were moving out of the old areas by the river to new terraces and villas on the rising ground to the south, leaving Hillgate and Pipewellgate to become tenemented, over-crowded and unhealthy:

"neither plan nor written description can adequately convey to the mind the true state and condition of the room-tenements and of the inhabitants occupying them. The subsoil on the sloping side of the hill is damp and most foul, the brickwork of the buildings is ruinous, the timber rotten; and an appearance of general decay pervades the whole district. The buildings fronting to Hillgate have originally been erected as residences of a superior description, the stairs have had carved balusters; the rooms have been fitted up with various forms of decoration, which only serve at present

1 R. Rawlinson, Report to the General Board of Health on a Preliminary Inquiry into the $[\ldots]$ Sanitary Condition [...] of Alnwick and Canongate (1850), p. 76. The unsatisfactory evidence of the figures of numbers of persons per house from the Censuses, which suggests that country towns such as Hexham and Alnwick had overcrowding levels similar to the large industrial towns, is confirmed by later specific enquiries into overcrowding. In 1911 the proportion of the population of the County Borough of Newcastle upon Tyne living at a density of more than two persons per room was 31.6\% ; for Alnwick and Belford Rural Districts it was, respectively, $30.0 \%$ and $31.3 \%$. In 1936, while Sunderland, with $20.6 \%$ of its working-class families living in overcrowded conditions, had the worst figure for urban areas, Norham and Islandshire in Northumberland, at $22.2 \%$, was the worst of the rural districts. Newcastle upon Tyne and Alnwick Rural District remained similar, respectively at $10.7 \%$ and $10.8 \%$. 
to heighten the grim misery which pervades them. Single rooms are let off as tenements which are crowded with men, women and children: the walls are discoloured with age, damp and rot; the windows are broken, old rags, straw and boards occupying the place of glass, so that means of light and ventilation are alike absent."'1

In the early 1850's one recently erected house in Victoria Street, Gateshead, contained five families of thirty persons in only six rooms (two of the families living in cellars), while in Leonards Court 342 people in 64 families lived in 20 houses and in Hillgate, admittedly in a large house, there were 71 people belonging to sixteen families. ${ }^{2}$ Dr Reid, a member of the Royal Commission on the Health of Towns, commented on Newcastle: "Some of the finest residences [...], the early abodes of the noble and the wealthy, with many of the advantages of modern civilization, parcelled into tenements, have been turned into the foulest shelters for the poor."3 Mid-nineteenth-century reports abound with similar evidence of the removal of the more prosperous, and the subsequent marked deterioration and over-crowding of once distinguished dwellings. At Gateshead the release of substantial blocks of land for housing later in the nineteenth century produced a large stock of new housing for workers in circumstances which will be discussed later.

It is sufficiently clear that in the first half of the nineteenth century house building frequently did not keep pace with the growth of urban population consequent upon industrial expansion, and severe overcrowding ensued. ${ }^{4}$ It is likely that the construction industry - to use a term utterly inappropriate to the collection of small builders of the

1 R. Rawlinson, Report [...] on a Preliminary Inquiry into [...] the Borough of Gateshead (1850), p. 27, quoted in Manders, op. cit., p. 163. See also D. B. Reid, Report on the State of Newcastle upon Tyne and Other Towns (1845); Report to the General Board of Health on Darlington, ed. by H. J. Smith (1850, reprinted by Durham County Local History Society, 1967); and F. W. D. Rogers, "Gateshead and the Public Health Act of 1848", in: Archaeologia Aeliana, Fourth Series, XLIX (1971), pp. 153-86.

2 Manders, op. cit., pp. 182-83.

3 Reid, op. cit., p. 89.

- The figures in the Censuses of Population for the number of houses and population of particular towns should provide adequate evidence on this topic. Unfortunately, the definition of a house varied considerably for some towns in the Censuses from 1801 to 1851 . As a result it was possible for South Shields and Westoe jointly to be credited with $833,1,514$ and 3,018 houses in the 1811,1821 and 1831 Census respectively, while population increased by only $20 \%$, and less houses in 1851 than 1841 although population has increased by $25 \%$. Despite these problems with the statistics there is general evidence to suggest that the number of persons per house increased between 1801 and 1851, with little likelihood that the average size of houses followed a similar pattern. 
time - was incapable of adjusting to meet the situation, but more importantly it is unlikely that many of the working men who moved to the towns - even if their earnings were high by previous standards could have afforded to rent a new house built on an urban site. When new building took place on any scale it usually came in areas away from the high-cost land in the existing towns, and in addition the kind of housing which appeared in large numbers later in the century, mostly in the form of the Tyneside flat, provided accommodation at a much lower rent than a similar-sized cottage would have entailed. Sunderland was unusual in its extent of later-nineteenth-century single-story housing.

It may be argued that local government should have acted to deal with the problems of poor housing and overcrowding. There is, however, little evidence of any widespread desire for or expectation of large-scale municipal enterprise of that kind until very late in the century, and ample evidence throughout to demonstrate a deep-rooted hostility, by no means confined to the rich, to the increase in rates and taxes which alone could have financed such projects. Popular pressure for expenditure on public-health measures, for example, tended to be fitful, with public concern evident when faced with immediate obvious danger, as from a cholera epidemic, but very much less evident in more normal times. Moreover, it is unrealistic to expect that the relatively primitive machinery of local government could have been expanded so substantially and rapidly as to control the effects of population growth and provide for the additional need for accommodation.

It was not only the poor who suffered from the sanitary defects of the time. Reid's 1845 report included this description of parts of North Shields:

"A very large portion of the modern or upper town is without sewers [...]. Owing to the imperfect and improper private drainage of some of the good and respectable houses in the upper town, the stench in several of them is very great at times. Some of the cesspools are located near several of the chief houses in the town, the inhabitants of which suffer great annoyance."1

A few years later the Sunderland Board of Guardians received the following letter from a very respectable address in Bishopwearmouth:

"We the undersigned beg to draw your attention to a nuisance $[\ldots]$ the house adjoins a back yard only parted from our yard by a thin brick wall. It contains a privy and a middenstead built against the wall, filth is seeping through so that our yard at the

1 Reid, op. cit., p. 109. 
present time is almost a foot deep in stinking water, the stench from which is very disagreeable and most unhealthy."1

The rate of industrial development and the growth of population in the first half of the nineteenth century, though they were to be outstripped later in the century, were beyond the capacity of those with power to cope with or even fully to comprehend them. In the second half of the century the pace of change accelerated, but the processes became better understood and were contained more satisfactorily, partly as a result of the expanding resources made available directly or indirectly by the continued growth of industry.

In the later nineteenth century such industries as coal-mining, iron and steel manufacture, shipbuilding and engineering took off into much faster growth and speeded up the development of the urban areas in which they were situated. This was the period in which large-scale industry took hold of the region and in which for the first time coal began to experience a challenge as the prime source of industrial importance. In the publishers' preface to The Industrial Resources of the Tyne, Wear and Tees, published in 1863, the following figures were given for the annual value of total output in the region: coal $£ 6.7$ million, metal products $£ 3.7$ million, shipbuilding $£ 2.3$ million and engines and machinery $£ 1.9$ million.

This marked narrowing in the predominance of coal was epitomised in Middlesbrough, certainly the major British town to develop from nothing during the century. After its dramatic growth in the 1830's Middlesbrough experienced a markedly slower rate of growth in the 1840 's, with a rise in population from 5,463 to 7,631 . The early industrial base of coal exporting had, as we have seen, been largely cut away by the development of the Hartlepools. The owners of Middlesbrough, however, still encouraged schemes for expansion, with Joseph Pease's driving force particularly important. As early as 1828 his optimism had been firm; in August of that year he had sailed up the Tees to study the suitability of Middlesbrough as a railway terminus, and wrote:

"Its adaptation far exceeded my anticipations. I was fancying the coming of a day when the bare fields we then were traversing would be covered with a busy multitude, and numerous vessels crowding to these banks denoting a busy seaport. Time, however, must roll many successive tides ere the change is effected. But who that has

1 P. A. Wood, "The Sunderland Poor Law Union, 1834-1930" (M.Litt. thesis, University of Newcastle upon Tyne, 1976), p. 45. 
considered the nature and extent of British enterprise, commerce and industry will take his stand at this spot, pointing the finger of scorn at the vision, and exclaiming that it will never be."1

When Pease died in $\mathbf{1 8 7 2}$ his vision had become a reality, and much of the achievement was the result of the efforts of Pease himself and his fellow Quakers among the Middlesbrough owners. They laid out housing plots, financed and encouraged the provision of social amenities, but, most importantly, they took great pains to encourage the establishment of industry in the area.

The seeds of much future growth were sown as early as 1841 , although the significance of this event was not to be apparent for a decade. In that year, at the invitation of Joseph Pease, Henry Bolckow and John Vaughan set up a foundry and rolling mill. Vaughan had accumulated experience and some money as a foreman at the Dowlais ironworks and then as manager of the Walker ironworks of Losh, Wilson and Bell, while Bolckow had demonstrated commercial acumen and acquired a substantial capital in a commercial partnership with Christian Allhusen, mainly concerned with the Tyneside corn trade. Over the next decade their Middlesbrough iron works expanded slowly, and when in 1846 they began to make their own iron, it was with the establishment of blast furnaces at Witton Park, near Bishop Auckland, based on local ironstone and coal. With the expanding demand for iron and iron products it was clear that the limited supplies of ore on which these and other works were based would prove unsatisfactory and alternative supplies would be sought. The existence of iron ore in the Cleveland Hills had been known since 1811 and limited amounts had been sent from Whitby to ironworks in the region, but it was John Vaughan who was primarily responsible for the successful commercial exploitation of the extensive deposits. ${ }^{2}$ Vaughan traced the main ironstone bed at Eston in June 1850. By the end of the decade the number of blast furnaces at Middlesbrough had risen from none to 32, almost half the total in the region. Teesside's output of pig iron had reached 305,000 tons and by 1870 grew to 1.7 million tons, and by that time 4 million tons of iron ore were being mined annually in Cleveland.

Middlesbrough's population responded dramatically. Between 1851 and 1854, the first years of exploitation of the Cleveland deposits, the town's population grew more than in the whole of the previous decade. In 1861 the figure was 18,$892 ; 1871,39,284 ; 1881,55,934$, and thirty

1 Quoted in W.Lillie, The History of Middlesbrough (Middlesbrough, 1968), p. 47.

2 A reliable account of the gradual exploitation of the ores, first from the coast near Whitby, inland at Grosmont and finally from Eston, is given in Bell, loc. cit., pp. 734-36. 
years later, 104,767. In the early years of this massive expansion the rate of growth produced the frontier-town image which Professor Briggs so neatly caught in the phrase "the British Ballarat". ${ }^{1}$ There was a low female/male ratio, as single men and married men moving in advance of their families crowded in to take the newly available jobs. Overcrowding developed, and already the early plans of the Middlesbrough owners for a town of 5,000 had been far out-distanced. The effects on housing conditions were rapid. The original plans had been conceived in generous terms; originally the "building plots were 200 feet long and 60 feet wide [...]. It was soon found necessary to subdivide the 200-foot plots, and back-to-back houses were often built in the courts within the reduced plots or in alleys which led on to the main streets."2 Thus even in a "green field" planned development cost pressures produced overcrowding and the production of the pattern of accommodation which Lady Bell described so vividly:

"there springs, and too rapidly, into existence a community [...] the members of which must live near their work. They must therefore have houses built as quickly as possible; the houses must be cheap, must be as big as the workman wants, and no bigger; and as they are built, there arise, hastily erected, instantly occupied, the rows and rows of little brown streets, of the aspect that in some place or another is familiar to all of us. A town arising in this way cannot wait to consider anything else than time and space: and none of either must be wasted on what is merely agreeable to the eye, or even on what is merely sanitary. [...] It is, unhappily, for the most part a side issue for the workman whether he and his family are going to live under healthy conditions. The main object of his life is to be at work; that is the one absolute necessity."3

Clearly it was not only the workman who gained from living close to his employment; there were also advantages for the employer. In Middlesbrough, however, as in other developing towns, many employers played a major part in developing other aspects of the urban community, without which these settlements would have been merely sprawls of population. At Middlesbrough Bolckow lived in the town until 1856, was an Improvement Commissioner from 1841 to 1853, Tees Conservancy Commissioner, first mayor and first MP, one of the first magistrates, first President of the Chamber of Commerce and

1 A. Briggs, Victorian Cities, (1963), p. 255.

2 N. Moorsom, The Birth and Growth of Modern Middlesbrough (Middlesbrough, 1967), p. 8.

${ }^{3}$ Lady Bell, At the Works (1907), pp. 2-3. 
Chairman of the Middlesbrough Exchange Company. In addition he was Governor of the town's Infirmary, and a generous benefactor to hospitals, schools, churches, and recreational facilities. Another local employer, Isaac Wilson, pottery and iron manufacturer, and director of the Stockton and Darlington Railway, succeeded Bolckow as mayor and as MP; he was also Chairman of the Tees Conservancy Commission, Agent to the Middlesbrough owners, a magistrate, Chairman of the School Board (1870-88), Director of the Water Company and first President of the Mechanics' Institute. The efforts of men like these had some effect on the town's direction during this period of massive expansion; Middlesbrough received a public park, the gift of Bolckow, in 1868, ${ }^{1}$ before Newcastle possessed such an amenity, and Middlesbrough became a corporate town in 1853 while Darlington, a much older town, remained under a local Board of Health until 1867.

Middlesbrough's economic growth was not without its difficulties. The increase in capacity for iron production following the boom of the early 1870's was followed quickly by a serious falling-off in demand for iron rails, and this produced bankruptcies among some of the weaker iron works - the Erimus Iron Co. in 1874, Swan Coates, Lackenby Iron Works and Tom Vaughan in 1876, and Hopkins, Gilkes and Co. among others in 1879. These were, however, partial set-backs within a general picture of growth. When Gladstone visited Middlesbrough in 1862 he commented upon "This remarkable place, THE YOUNGEST CHILD OF ENGLAND'S ENTERPRISE [...]. It is an infant, gentlemen, but it is an infant Hercules."'2 The infant Hercules duly demonstrated a continuing capacity for physical growth, with borough extension Acts in 1858, 1866, 1874 and 1913.

At the other end of the region the story of the much more mature urban community of Newcastle showed a different pattern. The difference was noted by Gladstone; speaking at Newcastle after his visit to Middlesbrough he commented: "I know not where to seek, even in this busy country, a spot or district in which we perceive so extraordinary and multifarious a combination of the various great branches of mining, manufacturing, trading and shipbuilding industry". ${ }^{3}$ Unlike Middlesbrough, where in 1871 some $59 \%$ of the working population was employed in iron and steel manufacture, the industrial structure of Newcastle continued to be a diversified one. Here again, though,

1 When opening the park Prince Arthur remarked that Bolckow had stood by the iron cradle in which Middlesbrough was born and had watched over the growing child with care. "He knows what it wants, and what its interests are." Briggs, op. cit., p. 259.

2 Ibid., p. 245.

3 Newcastle Chronicle, 11 October 1862. 
metal manufacture provided the most striking examples of increases in employment.

In some cases this represented the continued expansion of existing enterprises, as in the growth of $\mathrm{R}$. and W. Hawthorn's engineering works from an employment of about 1,000 in 1850 to some 1,500 in 1874. By the early twentieth century, when the full complement of engineering and shipbuilding enterprises of Hawthorn, Leslie \& Co. was fully at work, it provided some ten thousand jobs in Tyneside towns. ${ }^{1}$ Much was also due, however, to firms which came into existence in the second half of the century, especially Armstrong's great engineering, shipbuilding and armaments enterprises. In 1847 W. G. Armstrong set up a small-scale works for the manufacture of hydraulic equipment at Elswick, then an area of green fields to the west of Newcastle. Four years later this emerging suburb already had a population of 3,539 , which grew to 14,345 by 1861 and 51,608 by 1891 . Early in the present century Armstrong's total labour force numbered some 20,000 (a few thousand of these employed in shipbuilding yards down river from Newcastle, which helped to swell the population of other Tyneside towns). This was much the largest single firm in the region. Armstrong's main site at Elswick came to stretch over more than a mile of river frontage; while the housing of Armstrong's workers covered more than a square mile on the hillsides to the north and even this, as we shall see, did not satisfy the housing demand.

Although no other enterprise could rival Armstrong's in size there were many other points of industrial growth, including a variety of other engineering and shipbuilding enterprises. The role of Newcastle itself, however, changed somewhat, with the development of supporting facilities for the major industries. Many of the older forges and foundries, for example, moved out of the central area to the eastern and western fringes of the town, from Scotswood in the west to the Ouseburn valley in the east. There was a marked expansion in commercial activities and the employment they provided, and a growth in consumption activities such as brewing and soap-making. As a result of these varied changes, the area of the town expanded. To the north Jesmond grew slowly as a select suburb of large terrace houses with some large villas in the period 1851-71, with a rise in population from 2,089 to 3,068 . Thereafter the pace quickened; the suburb's population doubled in the 1870's and reached 15,364 by 1901. By then the commercial expansion of the city had induced a greater demand for middleclass housing, largely satisfied by filling in the previously open areas of

1 Institute of Mechanical Engineers, Newcastle meeting 1925, Notices of Works Open to the Visits of Members, p. 14. 
Jesmond with large terraced housing. In addition the ubiquitous Tyneside flat also appeared in the area as railways, horse trams, and from 1902 electric trams made it possible for workers to live further from their place of employment.

In Elswick the available land was almost completely built up by 1901, and slowly from the 1860's the housing pressure had spread northwards into the adjoining area of Benwell, which had hardly increased its population since 1801. Rapid growth there began in the 1880 's; from 4,736 in 1881 the figure leapt to 18,158 in 1901 and 27,049 in 1911. By contrast, the older suburb of Westgate, which had seen some of the early expansion beyond the walls in the 1830's and 1840's, as a result of growth in mining and metal manufacture together with the building of some select residential areas, failed to maintain its rate of growth. Westgate grew from 669 in 1801 to 16,477 in 1851, and although a figure of 30,264 was reached in 1891 its population declined slightly in the last decade of the century. The growth which took place there in the second half of the century partly comprised the filling-up of previously open spaces and squares, and a considerable amount of tenementing of large houses.

There were also important changes in the population of the older centre of Newcastle. In 1854 a disastrous fire destroyed some of the old, overcrowded areas near the river, and rebuilding there and in other parts of the old town favoured offices and warehouses rather than housing, which increased the pressure for accommodation in areas like Westgate, as well as making overcrowding worse in the surviving parts of the old town's housing. However, as the stock of newer housing mounted in the suburbs, and transport facilities expanded, there was a substantial decline in population in the old central area. The parishes comprising the main part of the old town reached their peak population (as far as the decennial census was concerned) in 1861 or 1871. Between 1861 and 1901 the population of St Nicholas fell from 7,487 to 2,608, that of St John from 7,730 to 3,250, and that of All Saints from 30,647 to 25,838 . A fourth parish, St Andrews, which made up the northern area of the old town, had more open space on which to build and reached a later peak of 19,637 in 1891 , but there too there was a decline, to 17,520 , by the end of the century.

To the east of the old town the pattern of development was similar but somewhat slower than that to the west. There was no major firm which matched Armstrong's in scale, but a gradual accretion of smaller industrial enterprises, and, as at Elswick, the areas nearer the river saw earlier growth. Byker's rapid expansion began in the 1870's, and its population rose from 10,704 in 1871 to 45,460 in 1901. A little further from the river, Heaton's growth dated mainly from the 1880 's, rising 
from 1,446 in 1881 to 16,007 in 1901 and 21,912 in 1911. By 1911 the expansion of industry and housing in Byker merged into the growth of the township of Walker further east and contributed to the concentrated ribbon of development along the North bank of the Tyne from Tynemouth to beyond Newcastle to the west, an urban expansion plainly derived from industrial growth. At Wallsend, under the influence of the expansion of shipbuilding and engineering, population grew from 6,715 in 1861 to 30,858 in 1901 . On the other side of the river the combined area of Monkton, Hebburn and Jarrow presented a similar picture, with an even more dramatic leap from a population of 3,835 in 1851 to 59,023 in 1901 , based on expansion in coal-mining, Palmer's inter-locking iron-making, shipbuilding and engineering enterprises, and another major shipyard, Hawthorn Leslie. The significance of shipbuilding was considerable at the turn of the century, with the North-East coast launching around half a million tons a year (about half of the United Kingdom's output) with about fifty per cent coming from the Tyne.

The story of Gateshead in the later nineteenth century provides another example of the varied relationship between town and industry within the region. Gateshead's dependence on industry was more complete than that of Newcastle, which had its important administrative, commercial and social activities. One of the main features of Gateshead's earlier growth was that it had contained a large proportion of the Tyneside chemical industry, but the prosperity of that sector reached its peak in the 1870's, although some firms survived longer than others; Allhusens were still providing about 1,000 jobs in the Gateshead area in 1890 . Fortunately the decline of one major industry was balanced by expansion in another, engineering, based for the most part on a few large firms. The old-established engineering and ironfounding firm of Hawks Crawshay had expanded to an employment of about 1,500 men in 1863 and a third more twenty-five years later. The winding up of the company in 1889 , however, caused considerable unemployment for a while, but other engineering firms were still expanding. Black, Hawthorn \& Co. employed about 1,000 in 1890 , though that company went into liquidation in 1896. In the 1890's John Abbot $\&$ Co., provided some 2,000 jobs in their Oakwellgate complex, while Clarke, Chapman \& Co. continued to grow at South Shore, providing about 2,000 jobs by 1907 . The population of the town had grown from 8,597 in 1801 to 24,805 in 1851 , but the second half of the century saw a much greater increase, to 47,808 in 1871 and 108,024 in 1901 .

This scale of growth imposed an enormous strain on Gateshead's housing resources, which was partly met by increasing the occupancy 
rate of existing houses and partly by new building as landed estates sold off land for housing purposes. ${ }^{1}$ In the period immediately after mid-century the older areas of the town saw an increase in over crowding, partly because of an influx of Irish in the 1840's and 1850's, and tenementing spread to the newer terraces just to the south of the old centre, and middle-class squares erected earlier in the nineteenth century became in-filled with housing of a much meaner character. This was accompanied by the building of more select housing further south again, in Bensham and Low Fell. ${ }^{2}$ From the 1860's onwards large tracts of the main landed estates around the town were released for housing, and this opened the way to the building of large housing estates with terraces of mainly two-roomed flats on the Park estate towards Felling to the east and on the Ellison estate towards Redheugh to the west. Between 1861 and 1881 this meant that the provision of housing increased more rapidly $(117.1 \%)$ than the rise in population $(98.6 \%)$ and the number of persons per house fell from 7.69 to 7.24. Much of this building was financed by local industrialists. In 1862, for example, John Sowerby and Samuel Neville, glass manufacturers, in partnership with J. W. Swinburne, the Town Clerk, bought eleven acres of the Shipcote estate for house-building, and subsequently made further purchases of the same kind; in 1867 Christian Allhusen, chemical manufacturer, and Hilton Philipson, a coal-fitter, bought part of the Park estate, on which they erected terraces of flats. Industrial capital made such housing developments possible and the houses were for the most part occupied by the recipients of industrial wages. Not all of this housing was to be occupied by workers in Gateshead enterprises. Just over the river Armstrong's booming empire had already seen the nearest sites for housing occupied, and the construction of the Redheugh Bridge in 1871 gave ready access to Elswick from those areas of west Gateshead which were just becoming available for housing development. This meant that increasing numbers of Gateshead men were employed in factories on the other side of the river, with consequences which will be discussed later.

By the later 1870's these intensive housing developments in Gateshead had eaten up most of the suitable land which was available, and

1 Manders, op. cit., pp. 164-71.

${ }^{2}$ The same pattern, of outward pressure from the centre with the tenementing of earlier middle-class property and the building of new middle-class dwellings further away from the centre, was to be seen in other towns in the North-East. See, for example, T. Corfe, Sunderland: A short history (Newcastle upon Tyne, 1973), p. 95. There is a discussion of the pattern of urban development in Sunderland in B. T. Robson, "An ecological analysis of the evolution of residential areas in Sunderland", in: Urban Studies, III (1966), pp. 120-42, and id., Urban Analysis: A study of city structure with special reference to Sunderland (Cambridge, 1969). 
this was reflected in a marked slowing down in building, such that between 1881 and 1891, while the population rose by $30.3 \%$ the number of houses increased by only $12.6 \%$. Then from the late 1880 's there was a resumption of large-scale building, as more land became available, and this second wave saw the erection of many larger three- or fourroomed flats, many of which were filled by more prosperous workers moving up from the poorer quality and size which had characterised the flats built in the first boom of circa 1865-75. Between 1891 and 1901 the rates of growth of population and housing were similar and in general the second half of the century saw considerable similarity in these rates in Gateshead, the numbers of persons per house rising only from 7.34 to 8.02 .

As on the North bank of the river, South Tyneside's industrial towns were becoming a continuous belt of urban growth from South Shields to west of Gateshead. The great period of expansion of industry was however drawing to a close, and the region's economy rested to a dangerous extent on a few staple industries at the end of the century coal, engineering and shipbuilding. Gateshead, was one of the first centres to experience serious difficulties, long before the inter-war period to which these are usually related. As we have already seen a number of large employers in the town failed in the latter part of the century. This produced not only unemployment, but also a loss of rate income to local authorities. Gateshead's increasing role as a dormitory for industry in neighbouring centres also contributed to local difficulties. The town had come to possess wide areas of housing of low rateable value but considerable need for social services. As increasing numbers of workers in Gateshead worked elsewhere, local authorities received no rate income from their employers. For example many Gatéshead men worked at Elswick, where in 1907-08 Armstrongs paid $£ 13,000$ in rates to Newcastle Corporation, but not a penny to either the Town Council or the Poor Law Guardians in Gateshead, who had to cope with serious social problems in what was very much a workers' town.

Tyneside was not of course the only area within the region to see tremendous industrial growth in the second half of the century. Neither were Middlesbrough and Teesside generally the only areas to benefit from the expansion in iron and steel production. In 1841 the Derwent Iron Co. was established at Consett, essentially on a virgin site, with the object of using local deposits of iron ore and coking coal. By 1850 the company possessed one of the largest blast furnace plants in the country. There was a transition to the use of Cleveland ores in the 1850 's, and increasingly from the 1870's imported ores were used. After a period of difficulty and uncertainty in 1857-64, when ownership of the 
enterprise changed hands, there ensued a period of steady expansion, with the development of a pattern of vertical integration on a large scale, the company controlling substantial collieries and iron ore mines, blast furnaces, and manufacturing processes for iron and steel products. In the latter part of the century the Consett Iron Company was consistently the most profitable iron and steel enterprise in the region. ${ }^{1}$ The impact on the district's population was dramatic. In 1841 it was a totally rural, moorland area with a population of 195; by 1861 there were almost 5,000 people living in Consett itself; and by 1901 more than 10,000, with a further 7,000 in nearby Benfieldside and many more in the surrounding mining communities.

As in other formerly rural areas population growth meant unusual pressures on housing provision, because it was impossible to crowd people, even temporarily, into existing accommodation. The Derwent Iron Company in its earlier years was faced with the need to provide housing on a large scale and by 1851 it owned some 1,300 cottages, ${ }^{2}$ largely by means of advances from its bankers, the ill-fated Northumberland and Durham District Bank, whose failure in 1857 owed more than a little to the large sums it had sunk in development at Consett. By the 1890's the company's successors had increased its stock to some 2,000 houses, and as a result of the development of the ironworks a town had been created from nothing in less than half a century. Inevitably the provision of rent-free houses to coal- and iron-working employees of Consett meant that wages were lower than at Witton Park, for example, where housing for Bolckow and Vaughan's workers was mainly rented from speculative builders, but it seems likely that the standard of housing provision was higher. This also seems to have been

${ }^{1} \mathrm{H}$. W. Richardson and J. M. Bass, "The profitability of Consett Iron Company before 1914", in: Business History, VII (1965), and A. S. Wilson, "The Consett Iron Company Limited: A Case Study in Victorian Business History" (M.Ph. thesis, University of Durham, 1973).

2 "Within ten years of the foundation of the works the company owned approximately 1,300 cottages", A. S. Wilson, "Consett: the development of a 'model' company town, 1840-1900", in: North East Group for the Study of Labour History, Bulletin, No 8 (1974). This figure seems high, when compared with the 1851 Census figures for Conside (Consett) of 537 houses with a population of 2,777 . The Company also had houses, although it is uncertain how many, at Benfieldside, where the number of houses rose from 181 in 1841 to 561 in 1851 , and at Leadgate, where the number rose from 106 to 736 . When the new Consett Iron Co. took over the business in 1864, there were "more than 1,000 freehold cottages" (Richardson and Bass, loc. cit., p. 84), and it is unlikely that any would have been built since 1857 . In 1848 the Newcastle agent of the Bank of England was told that $\mathfrak{f 4 0 , 0 0 0}$ had been spent in purchasing land and building houses for the workmen of the Derwent Iron Company. Bank of England Archives, Newcastle Branch Correspondence, 14 March 1848. 
generally true in mining communities. ${ }^{1}$ There is also evidence in the examples of green-field development of mining and iron-working communities, whether housing was provided by the employers or speculative housebuilders, that provision was more rapid, and multi-occupancy and overcrowding rather less common than in the large towns.

The substantial growth of the region's towns in the second half of the century led to an acceleration of the process whereby smaller existing communities became swallowed up in expanding towns. We have seen how on both banks of the river Tyne an almost continuous belt of industry and towns came into existence. Similar patterns can be seen in all the large towns. For example, "One pattern in Darlington's development has been for isolated settlements to spring up around industrial enterprises which were then gradually linked to the town by further spreading out from both directions. Three outstanding examples of this are the Station Road and Whessoe area, Bank Top and Albert Hill."'2

We have seen also that a major consequence of accelerated population growth was overcrowding, a social malady in which the region enjoyed an unenviable pre-eminence. This was almost as true of the new industrial towns as of the decaying centres of older towns undergoing transformation. At Middlesbrough, for example, Lady Bell noted at the end of the century that about one-third of the working-class houses contained lodgers. Overcrowding had become a feature of the older towns by mid-century at the latest, and in most cases this did not worsen seriously in the second half of the century. By the criterion of numbers of persons per house some North-East towns stood out among the black spots even in national terms. In 1861 Newcastle, with 7.8 persons per inhabited house, had the highest figure for any major town, followed by London at 7.7 and Liverpool's 6.7.

These figures are not in themselves adequate indices of housing standards, because the North-East region possessed a higher proportion of small houses than many other regions, and the Census definition of a "house" is in itself something less than exact. Nevertheless these figures do indicate lower standards of housing provision than the national average. The impression is confirmed by the more accurate figures provided by Censuses at the turn of the century of the number of persons per room. In $189134 \%$ of the population of County Durham

1 Seymour Tremenheere commented favourably, but probably in exaggerated terms, on housing at Consett, Report of the Government Mines Inspector, 1852. See also Wilson, "Consett", loc. cit., and J. Y. E. Seeley, "Coal Mining Villages of Northumberland and Durham: a Study of Sanitary Conditions and Social Facilities, 1870-80" (M.A. thesis, University of Newcastle upon Tyne, 1974).

Sunderland, op. cit., p. 102. 
were living at a density of more than two per room, while in Northumberland the situation was worse, at over 38\%. In comparison London, with just under $20 \%$ of its population living above the same density, provided the worst situation elsewhere. The figures for particular North-East towns included Gateshead $40.8 \%$, Newcastle $35.1 \%$ and Sunderland $32.9 \%$, but this was not a phenomenon of large urban areas, since among mining communities the 1911 census gave figures of $32.2 \%$ for Ashington, and $27.0 \%$ for Houghton-le-Spring.

These high figures were, however, more a regional phenomenon than anything distinctively urban or industrial. Many smaller colliery villages also saw high overcrowding, but so did rural communities; Norham and Islandshire in Northumberland, essentially agricultural in character, although including some small mining communities, returned a figure in 1911 of $34.1 \%$ living at a density of at least two per room. The overcrowding of the region was not then the result simply of population growth. Some other regions saw comparable population growth without comparable overcrowding, while rural areas in the North-East produced overcrowding without population growth. In this region, the housing stock expanded slowly, with many small houses included, but much of the explanation for the bad situation must lie in an existing low level of expectation for accommodation in both urban and rural areas, low levels which became endemic and accepted. ${ }^{1}$

Before the end of the nineteenth century there were, however, already some signs of improvement. We have already seen the change from the building of two-roomed flats to the building of three- and four-roomed flats in Gateshead, and similar improvements in house size occurred in mining housing in various parts of the region. Between 1891 and 1901 the level of overcrowding generally fell - in Durham from $34 \%$ to $28 \%$ of the population living at densities of more than two per room, and in Northumberland from $38 \%$ to $32 \%$. The improvement, however, was slow and, as Kenwood suggests, there was "No clear cut relationship between house-building activity and developments in the various industries"2 - and implicitly no clear-cut relationship between housing provision and population expansion. In the larger towns of the region, in particular, population growth had to be absorbed by existing accommodation, with new building lagging behind. In spite of rapid population growth and the overcrowding al-

1 It is interesting that the very high levels of migration into the region in the 1850 's and 1860's, and subsequent waves such as the migration into North Tyneside in the 1880's and the South-East Northumberland mining areas 18911911 , seem to have had little effect in raising standards of housing provision.

2 A. G. Kenwood, "Residential Building Activity in North Eastern England, 1853-1913", in: Manchester School, XXXI (1963). 
ready evident in the 1861 Census, the number of houses built in Newcastle fell from 387 in 1861 to 108 between 1862 and 1865.

It is clear that cyclical factors were one important element in the rate of housing response, usually with a delayed response to expansion in industry and population. ${ }^{1}$ In Middlesbrough housing approvals rose from an average of 347 annually between 1865 and 1870 to 1,027 between 1871 and 1876, following the boom in the iron industry in the early 1870 's, but then fell from a peak of 1,416 in 1875 to only 31 in 1880. Such patterns showed considerable local variation, however, for while the level of house-building was low at Middlesbrough in the 1880 's, it was higher in West Hartlepool, and on Tyneside, than it had been in the 1870's. As was the case nationally, there was a further housing boom in the North-East during the late 1890's and early 1900's, followed by a slump which continued until the First World War. It is worth noting, too, that in 1911 over $13 \%$ of Gateshead's houses and $11 \%$ of Newcastle's were uninhabited, in spite of the notoriously high level of overcrowding, suggesting that at the existing levels of rent and expectations of accommodation the market was saturated. With a population now growing more slowly and a large stock of small houses it is clear that a new housing boom was unlikely and overcrowding would prove intractable.

Ratepayer opposition to an increase in local-government expenditure remained a recurring feature of the North-East's towns, and this reluctance was fortified by the opposition of landlords and speculative builders whenever projects for municipal housing were aired. At Gateshead Alderman Dunn commented in 1899 that "dirty people made dirty houses. He would not interfere with their pleasure in filth", and a committee of the council "saw no reason for the building of workingmen's dwellings by the Corporation, as there were always plenty of that class of house to be procured within a reasonable distance."2 A few years earlier Alderman Richardson had sounded a similar note at Newcastle.

"There was a residuum of the population incapable of helping themselves. The residuum was the result, to a large extent, of hereditary causes, but mainly the result of a life of debauchery, sin and often crime [...]. If it was right and incumbent upon them to provide shelter for these people, it was equally incumbent upon them to provide food and raiment for them. Therefore the Corporation might begin and erect bakehouses and clothing establishments tomorrow. By that means, they would get themselves

1 See Kenwood, loc. cit.

2 Manders, op. cit., p. 171. 
upon an inclined plane, which would land them in the vortex of pure municipal socialism."

Early in the new century Newcastle Corporation nerved itself to embark upon a very small-scale housing project; when in 1909 it was learned that this adventure had resulted in a net loss to the rates of $£ 198$ there was a considerable row in the council, sparked off by the advocates of economy and non-interference. ${ }^{1}$

Gradually, however, in the early twentieth century these attitudes were overcome, and a number of North-East towns, including Newcastle and Gateshead, adopted housing programmes, but all on a very limited scale in relation to the contemporary problems of overcrowding and housing of poor quality. Other contributions came from unofficial sources, in the work of individuals or housing trusts and societies. At the end of the nineteenth and in the early twentieth centuries co-operative societies entered the housing arena; for example, the Crook society advanced $£ 35,000$ on mortgages to its members between 1899 and $1914 .^{2}$ Building Societies also played a part; when in 1906 the national conference of the Building Societies Association was held in Newcastle one of the speakers claimed, perhaps with some exaggeration, that "Those who are connected with Building Societies know perfectly well that working men have, in thousands of cases in Newcastle upon Tyne, purchased their houses - not only purchased their houses, but [...] were in a short time able to buy other houses, and have gone on until when old age came upon them they had a very good annuity." 3

Another source of improvement came through the gradual impact of changing national concepts of acceptable levels of housing provision. The 1872 Public Health Act, for example, had a marked effect in the North-East's mining communities, where considerable sanitary improvements followed its enactment. 4 Nevertheless the figures for overcrowding in the region in the early twentieth century show the magnitude of the problems inherited from the previous period of unprecedented expansion of industry and population. This was reflected in mortality figures. Using for comparison the crude death rate of 23 per thousand, at which under the 1848 Public Health Act towns could be required to set up a Local Board of Health, many of the region's towns

1 Newcastle Council Proceedings 1890-1891, pp. 430-31, and Proceedings 19091910 , p. 620. These references are derived from J. Noddings, "Working Class Housing in Newcastle upon Tyne, 1890-1914" (dissertation for the degree of Bachelor of Architecture, University of Newcastle upon Tyne, 1974).

${ }^{2}$ E. Lloyd, History of the Crook [...] Co-operative [...] Society Ltd. (Pelaw, 1916), p. 232.

3 Building Societies Association, Report of [...] Annual Meeting (1906), p. 73.

4 Seeley, op. cit. 
were above this level two decades and more later. Newcastle had a crude death rate of 24.8 per thousand on average for the years 1874-79, Middlesbrough a rate of 23.96 per thousand in 1871-73, and Gateshead a rate of 22.9 per thousand in 1881-83. It was not until after 1901 that Newcastle's rate fell permanently below 20 per thousand. Throughout the second half of the nineteenth century the major towns of the North-East had death rates a couple of points worse than the average for the country's large towns.

The period after the First World War is one in which the development of industry and the growth of towns is much less clearly defined as a relationship, and the number of relevant variables is too large to admit of any serious discussion here. A number of points may usefully be made, however. The nineteenth-century relationship between industrial development and urban growth was not generally reversible. The decline of the region's old staple industries in the inter-war period and later has not seen a decline in urban area, except in some small and highly specialised communities. There has been industrial development in some areas in forms which perpetuated similar relationships to those which created the industrial towns of the last century, as for example the expansion of urban area associated with the development of electrical engineering at Hebburn. The growing concern of central and local government, and a growing willingness and ability to intervene, have seen the deliberate creation of new industrial trading estates and even completely new towns called into existence by government decision. In essence, however, the continuation of urban expansion in the region has not depended on any direct relationship to industrial expansion, but much more on changing social concepts of acceptable accomodation, heavily influenced by the development of large-scale municipal housing projects.

Sometimes higher standards and greater resources were deployed to improve existing houses; for example, the availability of a government grant enabled Gateshead to embark upon a major programme of replacing dry closets with water closets, and in the two years after the grant was made available in 192518,700 houses received this conversion. ${ }^{1}$ A more important facet of continuing urban change, however, was the new building which took place, often in towns which had lacked the resources for effective action until central government grants were available. By 1936, for instance, Gateshead had built 2,360 council houses, while some of the most notorious old slums of the town, including Pipewellgate and Hillgate, disappeared after the Greenwood

I Manders, op. cit., p. 187. 
Act of 1930. The pace accelerated markedly after the Second World War; between 1946 and 1970 Gateshead built 10,686 council houses and flats.

But the scale of the inherited problems meant that a miraculous transformation was not achieved quickly. In 1936 , with $15.8 \%$ of its working-class families living in overcrowded conditions, Gateshead was the second most overcrowded county borough in the country. ${ }^{1}$ The 1951 Census showed Gateshead top of a list of 157 large towns in a number of important categories - the number of dwellings of only 1-3 rooms, density of persons per room, number of overcrowded households, and number of households with more than 1.5 persons per room. Since the Second World War, however, the dramatic growth of new building, together with slum clearance, has considerably reduced the impact of the nineteenth-century housing stock on current conditions. At Sunderland, for instance, some 20,000 houses were built in twenty years after the war, almost doubling the built-up area and requiring boundary extensions in 1951 and 1967.2

At the Southern end of the region the change has been perhaps even more marked. In Middlesbrough the population of the central wards, St Hilda's, Newport, Vulcan, etc., declined dramatically, while areas like Grove Hill and Linthorpe, away from the earlier industrial centre, doubled their population between 1921 and 1945. A recent historian of the town has written: "the face of Middlesbrough has changed. It really began as a trickle after the first world war, and after the second war reached avalanche proportions. Housing and rehousing have made a tremendous difference. All back-to-back development and the little courts of the old town have disappeared." 3

The movement from overcrowded, but intimate, communities has not been an unmixed blessing to the people concerned. The building of large, peripheral housing estates often meant that social, cultural and shopping facilities became more distant from the residences of the majority of the people, a problem which has only been partly alleviated by the extension of public and private transport and the building of suburban shopping and community centres. The new housing estates have often failed to re-create the closeness of the old neighbourly com-

1 North-East towns filled the first six places. Sunderland, at $20.6 \%$, was the most overcrowded, while following Gateshead came South Shields (13.1\%), Tynemouth $(13.0 \%)$, West Hartlepool $(10.9 \%)$ and Newcastle $(10.7 \%)$. Ministry of Health, Report on the Overcrowding Survey in England and Wales (1936), p. xvii.

2 Corfe, op. cit., p. 122.

${ }^{3}$ Lillie, op. cit., p.459. For the developments of the early period see The Social Background of a Plan: A Study of Middlesbrough, ed. by Ruth Glass (1948). 
munities of the older urban areas. In 1925 Douglas Golding wrote:

"Middlesbrough is a town which lives by its export trade, and when it ceases to be able to compete successfully in the markets of the world, it is difficult to see how it can continue. And so, perhaps in another fifty years or more, this hideous mushroom town will have shrunk back again into the arms of Mother Earth. Its tottering slums and jerry-built villas may relapse into mere mounds of brick on which the hardy wild flowers have seeded themselves.' 1

It may legitimately be doubted how far such romanticised conceptions as "this hideous mushroom town" have been shared by the mass of those who have lived and worked in Middlesbrough, and certainly now in the 1970's there is little sign of Golding's unconstructive vision turning into reality. Nineteenth-century growth has not turned into twentieth-century abandonment. In a variety of ways, including the development of the giant chemical complexes, the economy of Teesside has continued to expand, while at Middlesbrough, far from disappearing, the urban area has markedly expanded.

Although nineteenth-century urban growth was astonishingly rapid by the standards of any earlier period, in 1900 few residents of NorthEastern towns were more than a few minutes walk from open country. Yet within the space of two generations, with little overall growth in population, the neighbouring countryside has been eaten up and the older town centres bounded with horizon-stretching belts of modern homes. For the overwhelming majority of people this has involved a significant change. In what has been a relatively short period in historical terms there has been a kind of social revolution, in which the twin forces of industrialisation and urbanisation have been paramount influences.

Throughout the overwhelming majority of our history, men and women have lived and worked in small, locally-orientated communities in which interdependence was essentially between those who knew each other. Now home and work are often distant from one another, and all of the members of our industrialised and urbanised society are subject to very different kinds of interdependence. They depend for a complex range of services, production, distribution and entertainment on other people whom they do not know. The point can readily be illustrated by reference to one sector, public utilities. As towns expanded in the nineteenth and twentieth centuries, the provision of such services as gas, water and electricity took on increasingly sophisticated forms, in which very large areas of population came to depend for essential services

1 Quoted by Moorsom, op. cit., p. 46. 
upon the work of small groups of specialised workers, with whom in the nature of things they could have for the most part no acquaintance at all. In this area, and in other comparable areas, the related impacts of industrialisation and urbanisation have brought with them innumerable advantages, but they have also introduced new kinds of strains and risks to society. How far those strains can be sustained, and these risks avoided, will no doubt prove a fascinating field of study for future generations. 